\title{
Tourism Master Plans An Effective Tourism Destination Management Tool in SEE
}

\section{Sanja Cizmar and Sandra Lisjak}

\section{Abstract}

This paper examines the hypothesis that in SEE transitional economies there are two key success factors to insure the successful development of tourism. The first factor is the building up of an active role of government in structuring a state tourism strategy focused on increasing the international competitiveness of the given country's tourism sector. This would speed up the process of tourism development in a sustainable way, since the preservation of space and benefits for the local population should be the main strategic goals of future tourism development in SEE. The second success factor is the elaboration of tourism development master plans at a local level within the country, carried out with the broad involvement of stakeholders with a strong orientation towards pragmatic implementation. This paper uses the case study of Croatia, the most successful country in terms of tourism in SEE.

JEL: L83

DOI: $10.2478 / v 10033-007-0015-z$

\section{Introduction}

Since the 1980's we have used the definition of tourism as "... a basic and most desirable human activity deserving the praise and encouragement of all peoples and all Governments." (Burkart and Medlik, 1982, p. 59). Knowing that tourism is both a supreme good of modern civilization and a challenging economic sector that can have a serious impact on a significant part of the economic structure of a country or a region, it is worthwhile to understand how this fact is recognized in the transitional economies of South East Europe through its governments' influence on the development of tourism activity.

\section{SEE: The Economic Framework}

The degree of a government's active role in strategic planning and development of tourism depends heavily on the social and economic situation in the country or region.

SEE is defined by the European Commission as a diverse region consisting of nine countries located in the south-east corner of Europe, with a total area of $647.6 \mathrm{~km} 2$ and with 55.2 million inhabitants. This is a significant territory which includes Albania, Bosnia and Herzegovina, Bulgaria, Croatia, FYR Mace- donia, Moldova, Romania Serbia and Montenegro (The European Commission, 2007.). From the 1990's onwards, these countries have gone through military and political conflicts as well as economic crises. During the 1990's the region faced the transitional problems of inadequate economic growth, loss of investor confidence and declining living standards among its local populations. However, during the last couple of years there has been significant social and economic improvement in the region. Today, economic growth has resumed, institutions for the emerging democracies and market economies are being created and strengthened, regional trade links are being restored, private investment is slowly growing and the prospects for poverty reduction have improved (The European Commission, 2007.).

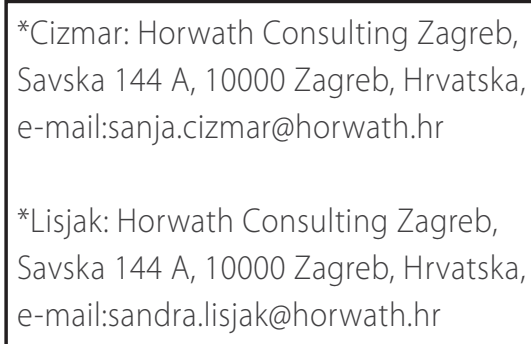




\begin{tabular}{|l|r|r|r|r|r|r|r|}
\hline & Albania & $\begin{array}{c}\text { Bosnia } \\
\text { And } \\
\text { Herzegovina }\end{array}$ & Bulgaria & Croatia & $\begin{array}{c}\text { Macedonia } \\
\text { FYR }\end{array}$ & Moldova \\
And & Romania \\
Montenegro
\end{tabular}

Source: World Development Indicators Database World Bank, http://devdata.worldbank.org , April 2006

\section{Table 1.}

Key Development Indicators of South East Europe Countries (2005)

Despite its encouraging socio-political and economic development, the region's countries remain uneven, with different economic structures, intensities of growth, levels of living standards and prospects for integration into the EU. Bulgaria and Romania joined the EU on January 1, 2007. The stabilisation and association process is the EU's policy framework for the Western Balkan countries: Albania, Bosnia and Herzegovina, FYR Macedonia and Montenegro. Croatia, which has started accession negotiations in October 2005, remains part of the process (The European Commission, 2007.). Integration with the European Union is an important factor for the further development of tourism in the countries of SEE.

Macroeconomic performance shows that SEE has a total GDP of US\$216.2 billion. Croatia has the highest GNI per capita, 2 or more times higher than in any other SEE country. The highest economic growth presently exists in Moldova and Serbia.
In evaluating the present degree of economic development in SEE countries and their future prospects, it should be noted first that most of its countries began the transition process with some basic elements of a market economy, and in recent years a strong revival of market forces is underway throughout the region. SEE should continue its progress in reform; the EU's Stabilisation and Association Process plays an important role in encouraging key aspects of this (EBRD, 2006). However, the reform agenda still includes many open issues that must be resolved in the future, such as restructuring enterprises, strengthening competition authorities, lowering market entry barriers, developing financial institutions and upgrading infrastructure networks (EBRD, 2006).

In line with the varying macroeconomic situations in different SEE countries, there are varying degrees of impact travel \& tourism will have on the region's individual national economies. Measured by Tourism Satellite Accounts (WTTC, TSA Research,

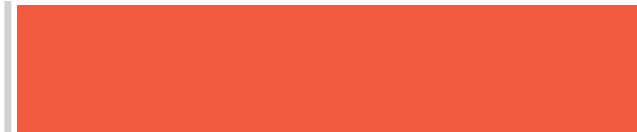

Economic activity that generate T\&T (in mio.)

Contribution of T\&T industry to GDP

Direct and indirect impact of T\&T economy to GDP

Direct employment of T\&T ind. (\% of total empl.)

Employment of T\&T economy ( \% of total empl.)

World ranking - Relative contribution to

national economy (out of 174 countries)

World ranking - Growth forecast (out of 174 count.)
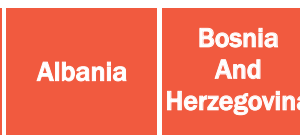

$\$ 1.853,2$

$3.8 \%$

$11.9 \%$

$3.1 \%$

$\$ 1.392,2$

$3.6 \%$

$11.8 \%$

$2.9 \%$

$9.5 \%$

$9.6 \%$

68

10

a

21

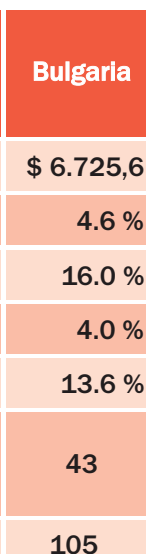

105

\begin{tabular}{|r|}
\hline Croatia \\
\hline$\$ 12.368,5$ \\
\hline $9.2 \%$ \\
\hline $20.1 \%$ \\
\hline $10,6 \%$ \\
\hline $23.1 \%$ \\
\hline 30 \\
\hline 5
\end{tabular}

5

\begin{tabular}{|c|}
\hline $\begin{array}{c}\text { Macedonia } \\
\text { FYR }\end{array}$ \\
\hline$\$ 610,2$ \\
\hline $1.5 \%$ \\
\hline $6.8 \%$ \\
\hline $1.5 \%$ \\
\hline $6.3 \%$ \\
\hline 139 \\
\hline
\end{tabular}

56

\begin{tabular}{|r|r|}
\hline Romania & Montenegro \\
\hline $\mathbf{\$} 7.071,5$ & $\$ 521,5$ \\
\hline $1.9 \%$ & $9.4 \%$ \\
\hline $4.8 \%$ & $15.7 \%$ \\
\hline $5.8 \%$ & $10.0 \%$ \\
\hline $6.9 \%$ & $16.8 \%$ \\
\hline 162 & 44 \\
\hline 4 & 1 \\
\hline
\end{tabular}

Source: WTCC Tourism Satelite Accounting Research 2006, http://www.wttc.org ,2007 Note: TSA Research for Moldova and Serbia is not available.

Table 2.

Impact of Travel and Tourism in Southeast Europe Countries (2006) 
2006), Croatia has the strongest economic activity generated by travel \& tourism in the region (US\$12.3 mil. in 2006), which is at least twice that of any other SEE country. In Croatia, travel and tourism make the highest contribution to the national GDP, and offer the highest share of employment of any country in the region. It is worthwhile to point out that, according to the same survey, out of 174 surveyed countries, Montenegro is ranked first in terms of forecasted travel and tourism growth. According to the same criteria, Romania is ranked 4th, and Croatia 5th, while other SEE countries have much lower T\&T growth prospects

\section{Hypothesis}

Keeping in mind the present economic situation of SEE, which is still marked by transitional features, as well as the impact of tourism on national economies and the growth prospects of various SEE countries, two key success factors emerge as the most important in insuring successful tourism development. First, it is of utmost importance for government to have an active role in the structuring of state tourism strategy. It should be focused on increasing the international competitiveness of its tourism sector. This would speed up the process of tourism development in a structured and sustainable way, and control the direction of its development, since the preservation of space and benefits for the local population should be one of the main strategic goals of future tourism development in SEE. The second factor of success is the elaboration of tourism development plans on a local level within the country, structured around the broad involvement of stakeholders with a strong orientation towards pragmatic implementation. In such circumstances, the tourism development master plan becomes an effective tool to achieve the challenging tourism development goals in the mid-term.

\section{Literature Review}

\subsection{Planning}

Planning is necessary to provide order and structure to human activities. According to Veal (1994), the problems of rapid urbanisation in the United Kingdom during the late 18th century provoked what are now seen as the roots of modern planning. Although actions then were mainly reactive, while today they are more proactive (Gunn, 1988) we are still in need of a holistic approach to planning (Butler and Hall, 1988).
According to Gunn (1988) and Williams (1998), the response to the urbanisation in the United Kingdom in the late 18th century in the form of Town and Country Planning, marks the beginning of modern Western planning. The aims of the Town and Country planning to minimise the negative impacts of urban development in terms of social and environmental issues, modern planning today shares as underlying principles. Furthermore, social and economic dimensions have been added to planning in recent years (Gunn, 1988):

Planning is a multidimensional activity and seeks to be integrative. It embraces social, economic, political, psychological, anthropological, and technological factors. It is concerned with the past, present and the future (Rose, 1984, in Gunn 1988, p.16)

However, the process of planning itself is not a straightforward process - it heavily relies on values, especially on the values of the local community (Gunn, 1988; Veal, 1994), which strongly suggests that planning should reflect the values of stakeholders and interest groups. Planning is also political (Gunn 1988), reflected in the need of governance in order for its implementation. Another necessary characteristic of today's planning is its continuity - planning needs to be continuous in order to incorporate new conditions in the process. Lang (1986), highlighted the differences between conventional planning and strategic planning, where the latter is practical as a process which implies action, rather than a static state (in Gunn, 1988)

As Williams (1998, in Leberman and Mason, 2002) and Gunn (1988) have stated, without planning there is the risk that an activity will be unregulated, formless or haphazard and likely to lead to a range of negative economic, social and environmental consequences. In short, the absence of planning leads only to malfunction and waste.

\subsection{Planning in tourism}

Tourism is seen by many as the world's largest industry, and as such it stimulates migrations of people, exploits resources, and impacts the environment, economy, and societies of the sites themselves. Tourism demands careful planning. In contrary to planning (or Town and Country Planning as it was originally known in Britain) tourism studies and tourism management have a much more recent history, and have only intensely evolved over the past few decades (Lavery, 2002).

In its earlier stages, tourism planning was essentially physical or land-use planning, with little or no consideration 
of issues relating to conservation or sustainable development (Lavery, 2002). Only in recent years have we seen recognition of the need for sustainable tourism development (in terms of economic, social and environmental impacts). Williams (1998) suggests that today, experiences around the globe imply that unplanned tourism development has negative impacts on tourism destinations. Furthermore, many authors (Gunn, 1988; Williams, 1998; Jenkins, 1991) argue that tourism planning is a necessary activity for all countries in order to develop tourism in a sustainable way. However, planning in tourism shows similar issues to those of planning in general, especially in the sense that both often views issues in isolation and that both are still rather reactive.

The key objectives of tourism planning, according to Williams (1998, in Leberman and Mason, 2002) include a framework for shaping and controlling the physical patterns of development, conservation of resources, as well as a framework for marketing destinations.

Planning in tourism is not a simple process, particularly because it requires various approaches - it can be done on a national, regional as well as a local level, which brings up issues of coordination (Williams, 1998). An additional complexity of tourism planning arises from the fact that it involves a variety of stakeholders - public bodies, the private sector, land owners, and many other user groups (Veal 1994; Williams, 1998), and is therefore difficult to operationalise.

Bearing all of this in mind, it is evident that tourism planning requires a policy, and in order to implement the plans we need governance (Fennell, 1999; Gunn 1988). The problem arises as from the view of governments that the responsibility of tourism policy lies with the private sector (Lickorish, 1991). Tourism planning and policy, in fact, is the responsibility of both the public and private sectors (Williams, 1998). This is one of the reasons why tourism planning is not as effective as planners would like it to be (Gunn 1988).

\subsection{The role of the Government in tourism planning and development}

The significance of tourism as a mechanism for economic development is recognised around the world. Cooper et.al. (1996) add that it is an investment opportunity that few governments can afford to miss. This view is supported by Gunn (1988), who states that this relatively recent phenomenon is increasingly demanding the attention of governments and citizens who previously regarded tourism with indifference.
Even though tourism is often (uncritically) referred to as a positive contributor to the economic, social and cultural development of destinations, it is necessary to consider its impact on the receiving or host communities (Jeffries, 2001). During the 1980 's more focus was put on new concerns in OECD countries - regional development, rural development and job creation, and the acknowledgement at the policy-making level of the potential positive as well as the negative impacts of tourism development (Jeffries, 2001).

Gunn (1988) states that only planning can avert the negative impacts of tourism. In other words, if tourism is to bring benefits, the concept of planning is necessary. However, planning must be implemented by all the stakeholders in tourism, and not only the planners (Gunn, 1988).

Furthermore, the last decade has seen an increased focus on the analyses and promotion of the non-economic benefits of tourism. The Guide for Local Authorities on Developing Sustainable Tourism (1998b, in Jeffries, 2001) states that carefully planned, developed and managed tourism could bring sustainable benefits to local communities, some of which include the following:

Tourism requires the development of adequate infrastructure, such as roads, water supply, electric power, waste management and telecommunications.

Tourism can provide new markets for local products such as agricultural and fishery products, arts and handicrafts and manufactured goods, and thereby stimulate other local economic sectors.

The overall environmental quality of an area may be improved as a result of tourism because tourists prefer to visit attractive, clean and non-polluted places. Land use and transportation patterns may also be improved because tourism serves as a catalyst for redevelopment.

Jeffries (2001, p.24-25) further lists the reasons for the attractiveness of tourism to governments, especially in the economically developing world, because of the opportunities inherent to the industry - its size, recent growth and a growing potential for future development; ubiquity; significance for the economy; conferment of potential economic values in natural, cultural and other heritage resources; contribution to the quality of lives of virtually all residents; and the relatively low pollution output of servicing organisations, compared to other major sectors of the economy.

I $t$ is clear, therefore, that tourism should elicit the governments' interest, and that it also requires governments' interven- 
tion. Even though policy documents, high-level reports and statements from ministries often regard the economic development of tourism as mainly a matter for the private sector, experience shows the crucial need for government intervention. Lickorish (1991, p.136-137) argues that sensible tourism planning is often handicapped by policy mistakes, confusion and lack of accepted leadership:

The government role is crucial. No one else can represent the whole community which is inevitably involved in large scale modern tourist development. Governments must decide policy, set the necessary rules, and accept public responsibility for the fair condition of trade, welcome and hospitality.

Thus, the public sector has the role of an operator, investor and trader, entrepreneur as well as a marketer, but also a strategic planner for long term development (Lickorish, 1991).

From the views presented here, it is also evident that even though governments play an indispensable role in tourism planning, the planning process increasingly involves a mix of private and public sector responsibilities, partnerships that provide more effective and sustainable results in tourism (Gunn, 1988).

(Covin and Slevin, 1991; Zahra and Pearce, 1994). Managers of both small and large-sized enterprises should, therefore, make creating an appropriate climate for intrapreneurship a top priority (Carrier, 1996). CE is especially important for larger organizations; while in smaller companies the boss or top management team represents the entrepreneurial spirit, in larger, more diffuse entrepreneurial firms it assumes the form of an entrepreneurial climate, or general atmosphere. Thus, the entrepreneurial action of the individual employees of a large organization - i.e. intrapreneuring (Pinchot, 1985) is attributed to a significant increase in a larger firm's performance (Antoncic and Hisrich, 2001) with the assumption that a large firm's natural advantage of economies of scale has been replaced by the economies of scope, or the organizational capacity to train and innovate.

\section{Tourism in SEE: The Strategic Perspective}

\subsection{Tourism Positioning}

In elaborating the hypothesis of the need for a strong governmental role in the strategic planning of future tourism development in SEE, we should first analyse the present status of the tourism positioning and competitiveness of its constituent countries.

In general, one should asses the SEE countries as "new," emerging tourism destinations, offering the international market tourism based on natural and cultural resources rather than artificially developed tourist attractions (which are still rare in this region). This is visible in the tourism positioning of these countries. In order to find out the current tourism positioning of SEE countries relative to the market, we have conducted an ad hoc internet survey using each country's official tourism web sites (http://www.albaniantourism.com, http://ww.bhtourism.ba, http://www.bulgariatravel.org, http://www.croatia.hr, http:// www.exploringmacedonia.com, hhtp://www.romaniatourism. com, http://www.serbia-tourism.org, http://www.turism.md, http://www.visit-montenegro.com, 2007). The survey revealed that the following tourism slogans of SEE countries are currently in use:

\section{- $\quad$ ALBANIA - The Last Secret}

\section{- BOSNIA AND HERZEGOVINA - The Heart-shaped Land}

- CROATIA - The Mediterranean As It Once Was

- MACEDONIA FYR - Cradle of Culture, Land of Nature

- MONTENEGRO - Breathtaking Beauty

\section{- ROMANIA - Come as Tourist, Leave as a Friend}

Bulgaria, Moldova and Serbia do not communicate with the tourist market on the basis of clear positioning (slogan), but position themselves based on the diversity of tourism ex periences.

The tourism logos, i.e., the visual identity of SEE countries for tourists, support the declared positioning of these countries. The SEE countries can be grouped into three categories according to the pillars of their tourism positioning. While some (Albania, Bulgaria, Montenegro) use the "sun and sea" as the basic USP in their visual identities, the other SEE countries emphasise the diversity of natural resources in visual communication with the market (Croatia, Macedonia, Moldova, Romania, Serbia). Only Bosnia and Herzegovina uses the hospitality 
of its people as its basic tourism USP.

\subsection{Tourism Organization Structures and Tourism Strategic Planning}

As far as state tourism organization structures in SEE are concerned, all the countries have ministries which are in charge of the implementation of state development policies in tourism. It is a common praxis that the ministry in charge of tourism is a department in the ministry with a broader mission (for example, economy or culture, youth and sports or sea, transport and development or trade, services etc.) (http://www.mkrs. gov.al, http://www.mi.government.bg, http://www.mmtpr.hr, http://www.economy.gov.mk, http://www.turism.md, http:// www.vlada.cg.yu, http://www.turism.ro, http://www.minttu. sr.gov.yu, January 2007). However, in all of the SEE countries such ministries are responsible for implementing state development policy in the field of tourism and coordinating the activities of the ministries and other public institutions. In some countries the national tourism marketing and advertising activities (as assistance to the activities of the regional, local and branch tourist organizations) are also part of the ministry's responsibilities (for example in Bulgaria), while in other countries, the National Tourism Board is in charge of national marketing and promotional tourism activities (for example in Croatia).

Based on such organisation structures, the strategic planning of tourism development is, in SEE countries, mostly under

\section{Tourism positioning based on sun and sea product}
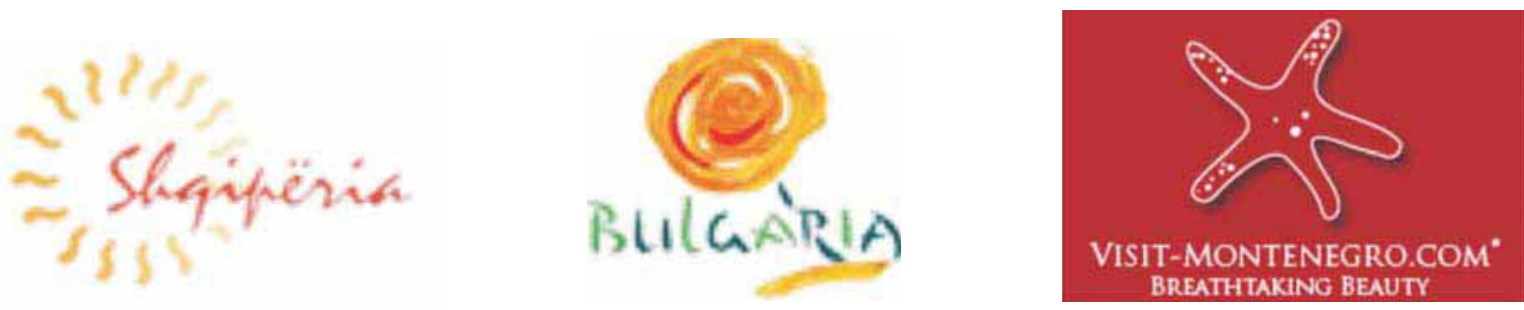

Tourism positioning based mostly on diversity of natural tourism attractions
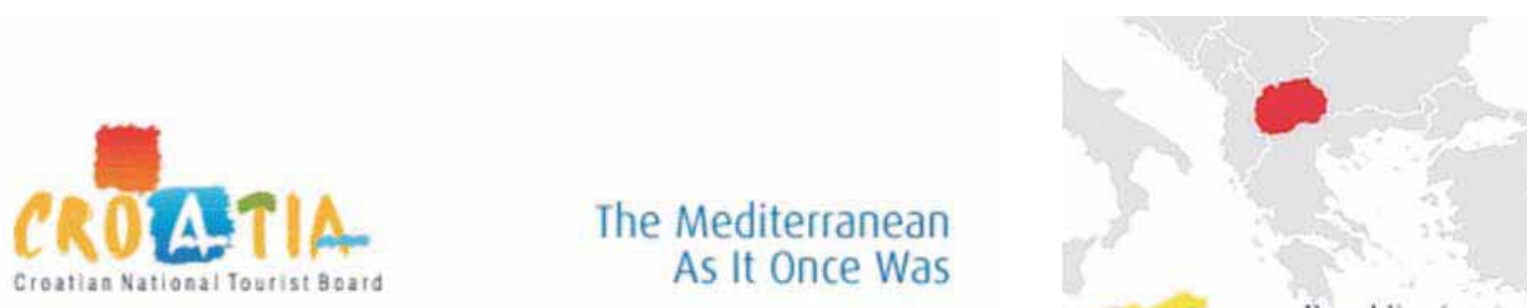

20 MACEublic of $\mathrm{MAO}$
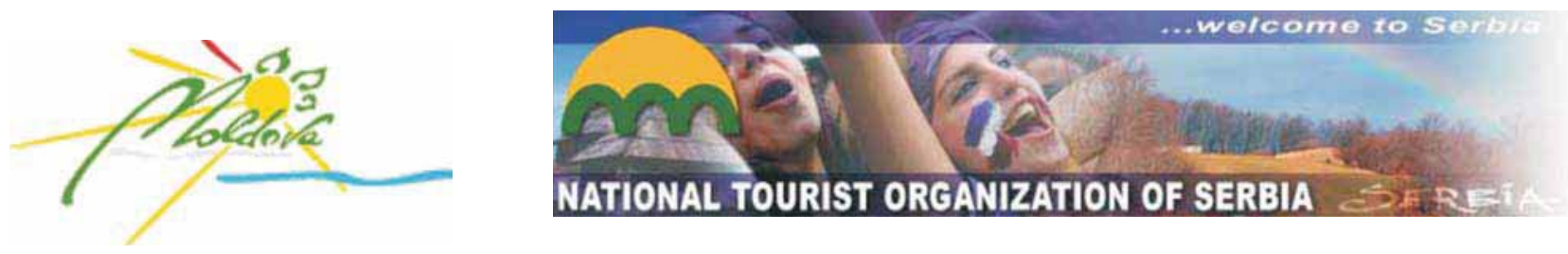

Tourism positioning based on hospitality

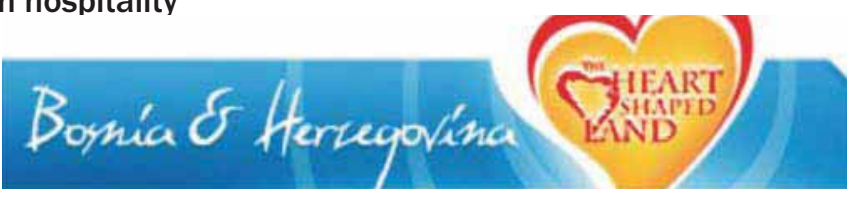

Source: Official tourism web sites of SEE countries (http://www.albaniantourism.com, http://www.bhtourism.ba, http://www.bulgariatravel.org, http://www.croatia.hr, http://www.exploringmacedonia.com, http://www.romaniatourism.com,http://www.serbia-tourism.org, http://www.turism.md, http://www.visit-montenegro.com), January 2007

Figure 1.

SEE COUNTRIES' TOURISM VISUAL IDENTITY 
the jurisdiction of the state ministry in charge of tourism. Therefore, in recent years, most state ministries in SEE have begun preparing strategies or master plans for tourism development in their countries. In some cases, such master plans or other strategic documents have been a part of international technical assistance or EU-aid programmes that aim at identifying a clear path of sustainable tourism development and building the capacities needed for the implementation of such plans. These strategic development projects, usually financed largely by the UNWTO (through its missions) or various EU-aid programmes, have constituted practical steps by the EU in assisting candidate and potential candidate countries in their preparations for joining the European Union. Such projects have the objective of preparing a comprehensive, integrated national tourism development policy, strategy and action programme that will provide guidance for the sustainable development of tourism in the country. Usually, the elaboration of a national tourism development strategy is the starting point for such projects, including product development strategy, legal framework improvement, institutional reform, human resources development, marketing improvement and natural resources protection. The main strategic objectives of such technical assistance projects carried out in SEE over the past two decades have been to build up a stronger and more efficient tourism sector in the country, to optimise the socio-economic benefits of tourism, alleviate poverty, to preserve, conserve and enhance cultural and natural heritage and involve local communities in the development process, and to foster public-private sector partnership (http://www.world-tourism.org, January 2007).

\subsection{Tourism Competitiveness and Tourism Development Master Plan}

If we apply Porter's concept of competitiveness to tourism in SEE, we can see that there is still a huge effort needed to establish satisfactory competitiveness among SEE countries' on the international tourism market.

As defined by the Concise Oxford Dictionary, competitiveness means to strive for superiority in a quality. This seems a very simple concept. However, the attempt to measure competitiveness reveals the ambiguity of this definition, because competitiveness is both a relative and a multidimensional concept (Ritchie and Crouch, 2003).

In terms of tourism competitiveness, most of the traditional reviews have focused mainly on the economic dimensions of destination strength and performance, which are only two of its several dimensions (Ritchie and Crouch, 2003, p.2): what makes a tourism destination truly competitive is its ability to increase tourism expenditure, to increasingly attract visitors while

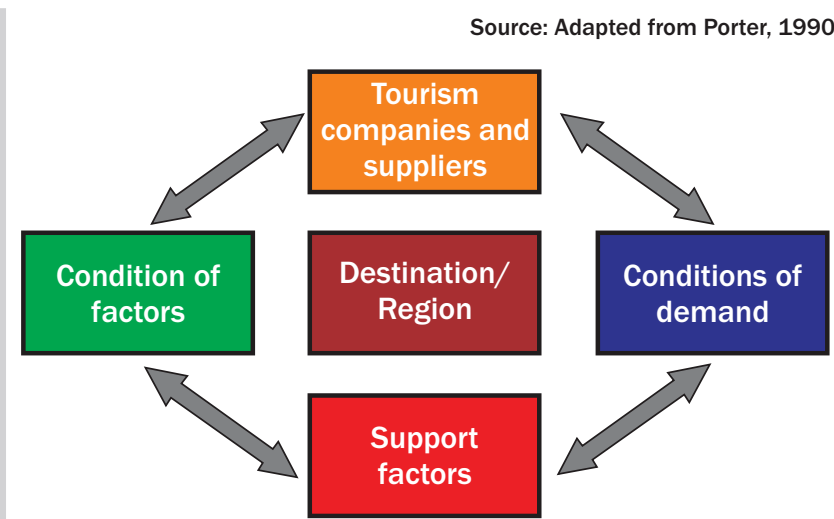

\section{Figure 2.}

The Competitiveness Diamond

providing them with satisfying, memorable experiences, and to do so in a profitable way, while enhancing the well-being of destination residents and preserving the natural capital of the destination for future generations.

Even though there seems to be no generally accepted definition of competitiveness- which can be viewed as a macroeconomic phenomenon (Porter, 1990)- for the purpose of this article and our views on the importance of government support in building competitiveness, we can add the view of Baker (1987, in Ritchie and Crouch, 2003, p.13) that 'Competitiveness - as much a cultural undertaking as an economic or political one - requires changing minds as much as changing policies'.

Considering the multidimensional nature of tourism competitiveness and its application to tourism, we offer the above diagram, adapted from Michael Porter (1990), who structured a national 'competitive diamond' in order to explain the determinants of national advantage in particular industries.

Applied to tourism in SEE, Porter's competitive diamond shows that the present status of tourism competitiveness in the region is inherited from non-market economies before the period of transition. Therefore, in order to establish a satisfactory level of tourism competitiveness in SEE, a huge effort is needed for the improvement of all four competitive forces.

Keeping in mind this elaboration of tourism competitiveness, a tourism development master plan could be used as an appropriate planning tool in building up the tourism competitiveness of a country or a region only if it is carried out according to a bottom-up principle by including the wide structure of local stakeholders in the process of its preparation.

Experience shows that tourism master plans, as regulatory documents, are common in countries that are in transitional phase from non-market to market conditions (Palman, Cizmar, 


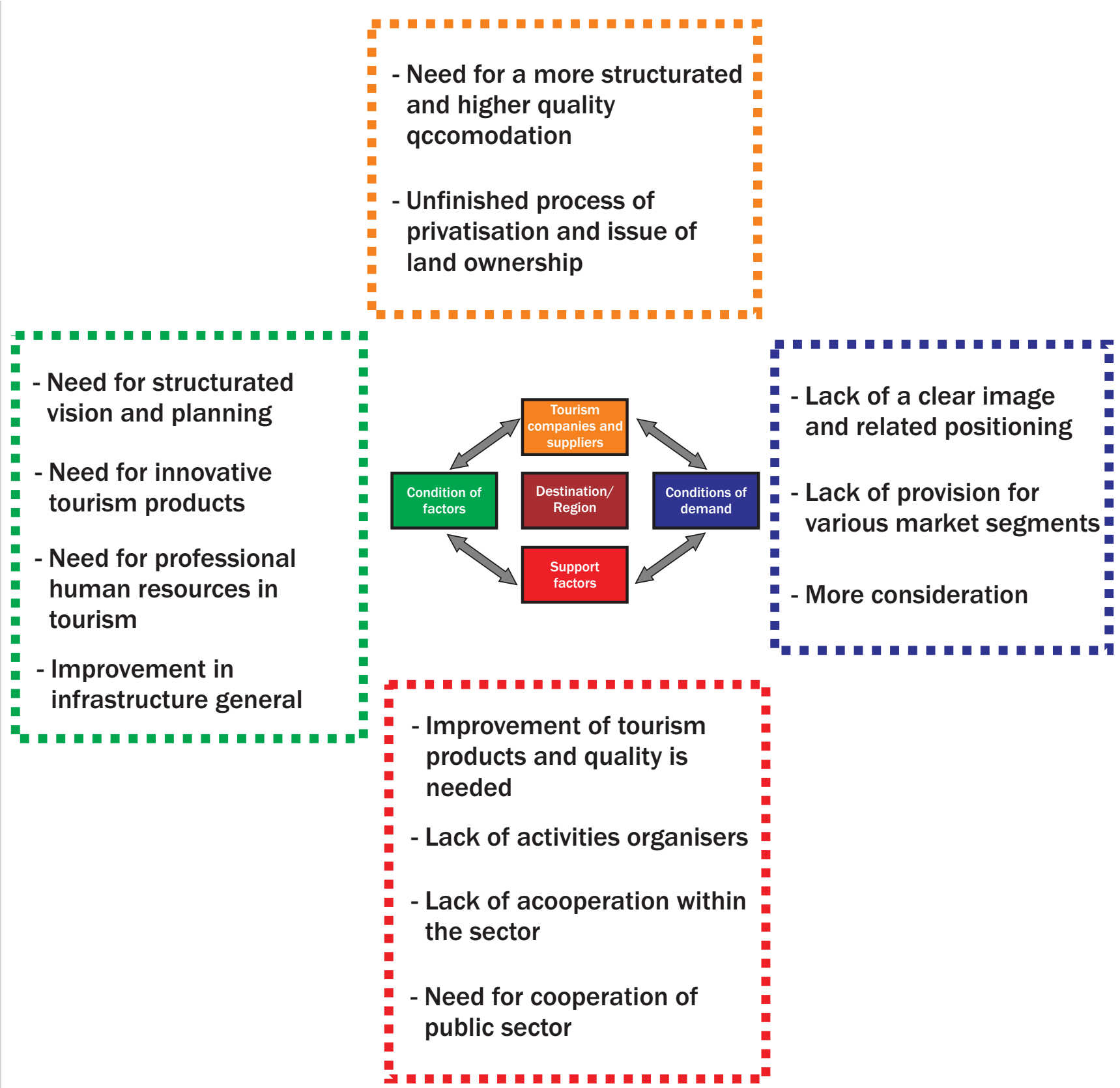

Figure 3.

The Tourism Competitiveness Status of the SEE Region

2004). They are also carried out for underdeveloped regions in developed market economies, thus creating regulatory frameworks to stimulate more intensive tourism development with available resources. In these cases, master plans focus on the tourism development of a specific zone that is not used for tourism purposes. They may also aim at repositioning a tourist area that is underperforming in terms of business results. However, it is common that developed market economies do not require master plans as stimulators of tourism development because they posses the developed general economic policies and pre-existing capacities (effective management structures responsible for tourism development) needed for tourism development guidance and implementation. In this context, when a country is at the very beginning of tourism development, or when it is in a phase of major change in its own social and economic systems, there is an obvious need for a master plan, since this represents an institutionalized platform according to which stakeholders can build a competitive tourism sector in their area (Dragicevic, 2006). Since the whole of SEE is still undergoing a process of socio-economic transition, a master plan represents the most effective strategic tool of tourism development. 


\section{Tourism Development Master Planning: The Case of Croatia}

Since Croatia is, in terms of its tourism and travel economy size, the most developed country in SEE, its patterns of tourism strategic and master planning should be used as a valuable example. Let us explore its approach to strategic and master planning at both the state and local levels.

Although traditionally a tourism oriented country, from the establishment of Croatia as an independent state at the beginning of the 1990's, and especially in the post-war period (the late 1990's) the Croatian Government has identified tourism as its economic sector of major strategic significance. Therefore, on a state level, from the 1990's onwards, the Croatian Government has made significant efforts to strategically define the future development of tourism in the country. From 1993 onwards, four different documents on tourism development strategy have been formulated, with three in the period from 2002 to 2003 (DEG - 2002; Institut za turizam - 2002; McKinsey - 2003; Hotel Partner - 2003) aiming to design a high quality, modern and innovative tourism supply that would increase the competitiveness of Croatian tourism in international markets (Ministry of Tourism, 2003). With these efforts of Ministry of Tourism, the strategic framework of Croatia's future tourism strategy has been set. Concurrently, the Croatian National Tourism Board initiated and ordered the preparation of the Strategic Marketing Plan of Croatian Tourism for the period from 2001-2005 (THR and Horwath Consulting Zagreb, 2001). This strategic marketing plan designed the tourism positioning of the country under the slogan "The Mediterranean as It Once Was", and has set up product development and marketing strategies which, in their implementation phase, proved a great success.

It should be pointed out that all of the above-mentioned strategic documents formulated a state-level tourism strategic framework. There are several key success factors in Croatia's international tourism market success connected with the elaboration of a master planning process initiated at the beginning of the new millennium (from 2000 onwards). They are as follows:

\section{BOTTOM-UP PRINCIPLE APPLIED IN SEVERAL}

LOCALITIES: Starting with the most important tourist region of Croatia, Istria (with importance measured by its tourism economy size), several local master plans have been prepared and elaborated in the last five years. The localities of Istria, Primorsko-goranska, Sibensko-kninska, Split-Dalmatia (all of them situated on the Adriatic coast) have prepared their own master plans. Several other continental localities' tourism master plans are currently under way.

2. HIGH INVOLVEMENT OF STAKEHOLDERS: The most important factor of success was the approach that was chosen in the process of preparation and elaboration of most of these local master plans. The broad network of stakeholders has been involved in a numerous series of workshops that were held in the cities, towns and villages across the localities where master planning has been carried out. This broad involvement principle has insured that all the important initiatives of different stakeholders have been analysed and, if aimed at increasing the county's tourism competitiveness, included in the Action Programme defined by each master plan.

3. MASTER PLAN STRUCTURE AND FOCUS: Most of the abovementioned tourism master plans have been focused on the development of key determinants of competitiveness: vision and positioning, product plans, competitiveness plans, investment plans and action plans.

4. PRAGMATIC AND IMPLEMENTATION-ORIENTED: The other significant element of success is the fact that most of these tourism local master plans are very pragmatic and implementation-oriented. For example, the first local tourism master plan developed in Croatia was based on the abovementioned principles. The Istrian master plan (THR and Horwath Consulting Zagreb, 2003) realised over $50 \%$ of its investments within the first three years of its implementation. Investment in services and competitiveness has already been exceeded, with another six years to go. Investment in accommodation is almost there, while investment in infrastructure has been well-exceeded (Napier, 2007).

\section{Conclusion}

Since South East European countries still feel the consequences of their transitional periods, the active role of governments in the strategic guidance of future tourism development can both affect its more intensive development and control the sustainability of tourism development and its impacts on the local population's welfare. Besides the need to set a state tourism strategy, in order to build tourism competitiveness in transitional economies (such as those in SEE), the key success factor is the design of a series of tourism master plans at a lower (local) level. In order to be an effective tool of tourism development planning, the master plan should be designed based on the following principles: a bottom-up principle, high involvement among all stakeholders, structure and focus on the key determinants of competitiveness, and a pragmatic, implementation-oriented approach. 


\section{References}

Albania - Ministry of Tourism, Culture, Youth and Sports, http://www.mkrs.gov.al , January 2007

Bulgaria - Ministry of Economy and Energy, http://www. mi.government.bg, January 2007

Burkart, Arthur John, and Medlik, Slavoj, "Tourism Past, Present and Future", 2nd ed, London, Heinemann, (1982): 59

Butler, Richard W. and Hall, Colin Michael, “Tourism and recreation in rural areas: Myth and reality. In Rural Tourism management: Sustainable Options, ed. D. Hall and L. O'Hannon, pp.97-108. Ayr: Scottish Agricultural College, 1998

Cooper Chris, Fletcher John, Gilbert David and Wanhill Stephen. (1996) “Tourism Principles and Practices”. London: Longman, 1996

Croatia - Ministry of the sea, tourism, transport and development, http://www.mmtpr.hr, January 2007

Dragicevic Miroslav, "Is It Possible to Rearrange croatian Tourism by Master Plans for Tourism Development”, Horizons, Horwath Consulting Zagreb, (2006) : 10-11

European Bank for Reconstruction and Development, "Transition Report 2006”, London, (2006): 9

Fennell, David, "Ecotourism: An Introduciton", London: Routledge, 1999

Gunn, Clare A., "Tourism planning”, 2nd edition, New York: Taylor and Francis, 1988

Horwath Consulting Zagreb, “Tourism Development Master Plan of Split-Dalmatia County 2006-2015”, Zagreb (2006)

Jeffries, David, "Governments and tourism”, Oxford: Butterworth-Heinemann, 2001

Jenkins, Carson L., "Tourism development strategies". In Developing tourism destinations, ed. L. J. Lickorish, pp.61-77, Harlow: England, 1991

Lavery, Patrick, “Tourism Planning”, Huntingdom: Elm Publications, 2002

Leberman, Sarah I. and Mason, Peter, "Planning for recreation and tourism at the local level: applied research in the Manawatu region of New Zealand”. In Tourism Geographies 4(1), pp.3-21, 2002

Lickorish, Leonard J., "Developing Tourism Destinations: Policies and Perspectives, Harlow: Longman, 1991

Macedonia FYR - Ministry of Economy, http://www.economy.gov.mk , January 2007

Moldova - Ministry of Culture and Tourism, http://www. turism.md, January 2007

Montenegro - Ministry of Tourism and Governmental Protection, http://www.vlada.cg.yu, January 2007
Napier Barry, "First Three Year Review of Istria's Tourism Master Plan”, http://www.hotel-online.com, January 2007

Official tourism web sites of SEE countries (http://www. albaniantourism.com, http://www.bhtourism.ba, http://www. bulgariatravel.org, http://www.croatia.hr, http://www.exploringmacedonia.com, http://www.romaniatourism.com, http://www. serbia-tourism.org, http://www.turism.md, http://www.visitmontenegro.com), January 2007

Palman Adriano and Cizmar Sanja, "Why is Croatia in Need of Tourism Master Plans?", Horizons, Horwath Consulting Zagreb, (2004):10-11

Porter, Michael E., "The Competitive Advantage of Nations, New York: Free Press, 1990

Republic of Croatia, Ministry of Tourism, "Strategy Report - Croatian Tourism Development by 2010”, Zagreb 03

Ritchie, J.R. Brent and Crouch Geoffrey, "The Competitive Destination: A Sustainable Tourism Perspective, Oxon:CABI Publishing, 2003

Romania - Ministry of Tourism, http://www.turism.ro , January 2007

Serbia - Minstry of Trade, Tourism and Services, http://www. minttu.sr.gov.yu , January 2007

The European Commission, “Status of SEE countries' relations with the EU”, http://www.seerecon.org/gen/eu-see.htm, January 2007.

The European Commission, "The European Commission and EU policy towards South East Europe", http://www.seerecon.org/gen/ecrole.htm, January 2007.

The European Commission, "What is the economic situation in the Region?", http://www.seerecon.org/gen/econsituation. htm, January 2007.

THR and Horwath Consulting Zagreb, "Strategic Marketing Plan of Croatian Tourism 2001-2005”, Barcelona-Zagreb (2001)

THR and Horwath Consulting Zagreb, "Tourism Development Master Plan of Istria 2004-2012”, Barcelona-Zagreb, (2003)

Veal, Anthony James, "Leisure policy and planning, Harlow: Longman, 1994

Williams, Stephen, “Tourism geography”, London: Routledge, 1998

World Bank, World Development Indicators Database, http://devdata.worldbank.org, April 2006.

World Travel \& Tourism Council, "Tourism Satellite Accounting Research 2006”, http://www.wttc.org, December 2006.

WTO Technical Cooperation, http://www.world-tourism. org , January 2007 